\title{
Evaluation of Phenolic Compounds in Rhizomes of Three Renealmia L. f. Species: Quantification, Antioxidant Activity and Histolocalization
}

\author{
Gevú, K. V.; Castro, R. N.; Souza, J. P. L. M.; da Silva, I. G.; Lima, H. R. P.; \\ da Cunha, M.; de Carvalho, M. G.*
}

Rev. Virtual Quim., 2019, 11 (5), 1625-1634. Data de publicação na Web: 31 de outubro de 2019

http://rvq.sbq.org.br

\section{Avaliação das Substâncias Fenólicas em Rizomas de Três Espécies de Renealmia L. f.: Quantificação, Atividade Antioxidante e Histolocalização}

Resumo: A histolocalização das substâncias fenólicas foi feita por técnicas usuais em Anatomia Vegetal. A determinação do teor de fenóis totais e do teor de flavonoides foram realizadas por métodos espectrofotométricos. A atividade antioxidante foi avaliada pelos métodos DPPH, ABTS e FRAP. Todos os extratos avaliados apresentaram capacidade antioxidante; entretanto, os melhores resultados foram para os extratos de $R$. nicolaioides. Correlação positiva foi encontrada entre o conteúdo total de fenólicos e os ensaios de capacidade antioxidante. Os resultados são inéditos para o gênero em questão e contribuem para novas pesquisas sobre substâncias fenólicas e suas atividades antioxidantes.

Palavras-chave: Fénois totais; flavonoides; radicais livres; histoquímica; órgãos subterrâneos;

Zingiberaceae.

\begin{abstract}
The histolocalization of phenolic compounds in Renealmia was performed by usual techniques in plant anatomy. Determination of total phenol content and flavonoid content were performed by spectrophotometric methods. Antioxidant activity was evaluated by DPPH, ABTS and FRAP methods. All the evaluated extracts had antioxidant capacity; however, the best results were for extracts of $R$. nicolaioides. We found a positive correlation between total phenolic content and antioxidant capacity assays. The results are unprecedented for the genus focused and contribute to further research on phenolic compounds and their antioxidant activities.
\end{abstract}

Keywords: Flavonoids; free radicals; histochemistry; total phenols; underground organs; Zingiberaceae.

\footnotetext{
* Universidade Federal Rural do Rio de Janeiro, Instituto de Ciências Exatas, Departamento de Química, CEP 23890-000, Seropédica-RJ, Brazil.

$M$ mariogdecarvalho@gmail.com

DOI: 10.21577/1984-6835.20190114
} 


\section{Avaliação das Substâncias Fenólicas em Rizomas de Três Espécies de Renealmia L. f.: Quantificação, Atividade Antioxidante e Histolocalização}

Kathlyn Vasconcelos Gevú, ${ }^{a}$ Rosane Nora Castro, ${ }^{b}$ Juliana Paes Leme de Mello Sousa, ${ }^{b}$ Ilna Gomes da Silva, ${ }^{\text {b }}$ Helena Regina Pinto Lima, ${ }^{c}$ Maura da Cunha, ${ }^{a}$ Mário Geraldo de Carvalho ${ }^{\mathrm{b}, *}$

a Universidade Estadual do Norte Fluminense, Centro de Biociências e Biotecnologia, CEP 28013-602, Campos dos Goytacazes-RJ, Brasil.

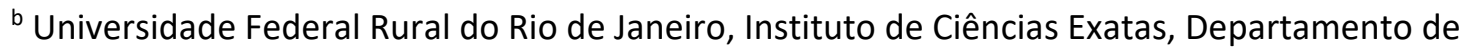
Química, CEP 23890-000, Seropédica-RJ, Brasil.

c Universidade Federal Rural do Rio de Janeiro, Instituto de Ciências Biológicas e da Saúde, Departamento de Botânica, CEP 23890-000, Seropédica-RJ, Brasil.

\section{*mariogdecarvalho@gmail.com}

Recebido em 30 de setembro de 2019. Aceito para publicação em 30 de setembro de 2019

1. Introduction

2. Materials and Methods

2.1. Plant material

2.2. Histochemical tests

2.3. Preparation of extracts

2.4. Determination of total phenolic content

2.5. Determination of total flavonoid content

2.6. Free-radical scavenging assay (DPPH)

2.7. Evaluation of antioxidant activity by ferric-reducing antioxidant power assay (FRAP)

2.8. Determination of antioxidant activity by radical-cation scavenging (ABTS ${ }^{+}$)

2.9. Statistical analyses

3. Results and Discussion

3.1. Secondary metabolites in rhizomes

3.2. Total phenolic and flavonoid content

3.3. Antioxidant capacity

Phenolic compounds are constituted by one or more aromatic nuclei containing hydroxylated substituents and/or their 
functional derivatives, and the flavonoids belong to this group. ${ }^{1}$ Plant polyphenols are multifunctional and can act as antioxidants by removing or inactivating free radicals. This activity consists of the donation of hydrogen atoms, present in the phenolic hydroxyls, or the performance of these substances as chelating agents/metal ion hijackers, inhibiting lipid oxidation. ${ }^{2-4}$

The side effects produced by synthetic antioxidants have generated a search for natural and less toxic compounds, especially those of derived from plants. Protecting cells against oxidative damage may prevent chronic diseases, such as cancer and cardiovascular diseases. ${ }^{5}$

Renealmia L.f. belongs to the family Zingiberaceae, subfamily Alpinioideae and Alpinieae tribe, and presents approximately 75 species distributed through tropical regions of the Americas and Africa. ${ }^{6,7}$ Renealmia is the only native genus in Brazil, and is represented by 21 species distributed throughout all phytogeographic domains, and most of these species are found in Amazonia. ${ }^{8}$ Most of these species are used as ornamental, medicinal and/or food. ${ }^{9}$

Anatomical and histochemical studies detected phenolic compounds were in the cortical region and central cylinder in rhizomes of ten species of Zingiberaceae. ${ }^{20}$

Some studies involving the identification of phenolic compounds in the rhizomes and the antioxidant activity of different extracts have been performed for the Zingiberaceae family, but more has included Renealmia species. ${ }^{11-20}$ The total phenolic content and antioxidant capacity of leaf methanolic extracts belonging to five species of Etlingera were quantified, and a positive correlation was found between these variables. ${ }^{12}$ The same was observed for leaf extracts and rhizomes of Alpinia, Boesenbergia, Curcuma, Kaempferia and Zingiber. ${ }^{15,17,18,20}$ Phytochemical analysis and antioxidant activity of aqueous and ethanolic extracts of leaves detected flavonoids, saponins, tannins and steroids from Amomum muricarpum Elmer, Etlingera philippinensis (Ridl.) R. M. Sm. And Hornstedtia conoidea
Ridl. ${ }^{19}$ The antioxidant activity, evaluated by the DPPH method, was slightly better for leaf extracts ( $E_{50} 0.25$ - $0.93 \mathrm{mg} \cdot \mathrm{mL}^{-1}$ ) when compared to rhizome extracts $\left(E_{50} 0.26-1.82\right.$ $\left.\mathrm{mg} \cdot \mathrm{mL}^{-1}\right){ }^{19}$

This work aims to determine total phenolic and flavonoid content and assess the antioxidant capacity of methanolic extracts of rhizomes from three species of Renealmia, as well as the histolocalization of the phenolic compounds in this organ.

\section{Materials and Methods}

\subsection{Plant material}

Renealmia species were collected at the Southeastern and Northern regions of Brazil. Renealmia chrysotricha Petersen were collected at the Parque Nacional de Itatiaia (2227'54"S 4446'11"W), Rio de Janeiro. Renealmia breviscapa and $R$. nicolaioides were collected at the Acre State, in the following areas: Fazenda Experimental Catuaba $\left(10^{\circ} 4^{\prime} 40^{\prime \prime} \mathrm{S} 67^{\circ} 37^{\prime} 35^{\prime \prime} \mathrm{W}\right)$ and Reserva Florestal Humaitá $\left(9^{\circ} 45^{\prime} 17^{\prime \prime} S 67^{\circ} 40^{\prime} 15^{\prime \prime} \mathrm{W}\right)$. The material was identified and deposited in the Herbarium of the Universidade Federal Rural do Rio de Janeiro (RBR) voucher 33416 for $R$. chrysotricha, and in the Herbarium of the Universidade Federal do Acre (UFACPZ) vouchers 6645 and 6646 for $R$. breviscapa and $R$. nicolaioides, respectively.

\subsection{Histochemical tests}

Histochemical tests were performed on freehand sections of rhizomes to detect phenolic compounds. The reagents used were $10 \%$ potassium dichromate and HoephnerVorsatz. ${ }^{21,22}$ Freehand sections not exposed to specific reagents were used as controls. The tests were performed in triplicate. 


\subsection{Preparation of extracts}

Air-dried powdered rhizomes were exhaustively extracted with $\mathrm{CH}_{3} \mathrm{OH}$ (PA, Vetec) at room temperature. The periodicity of solvent exchange was on average 48 hours, and each solution was concentrated on a rotary evaporator under vacuum. This process yielded three extracts which were subjected to liquid-liquid partitioning by organic solvents of increasing polarity (dichloromethane, and ethyl acetate, both PA, Vetec). The aqueous fractions (RBM-Aq, RCM$\mathrm{Aq}$ and RNM-Aq) of three species, dichloromethane fraction of $R$. nicolaioides (RNM-D), and ethyl acetate fraction of $R$. chrysotrycha (RCM-Ac) were evaluated.

\subsection{Determination of total phenolic content}

Total phenolic content of rhizome extracts was determined using the spectrophotometric-based modified FolinDenis method. ${ }^{23,24}$

Solutions of $1 \mathrm{mg} \cdot \mathrm{mL}^{-1}$ rhizome extracts in spectroscopic methanol were prepared. A 0.5 $\mathrm{mL}$ aliquot of this solution was mixed with 2.5 $\mathrm{mL}$ of Folin-Denis reagent. After $5 \mathrm{~min}, 2.0 \mathrm{~mL}$ of the previous solution was added to $14 \%$ fresh aqueous sodium carbonate solution. After $2 \mathrm{~h}$ the color of the green solution turned to blue, with the absorbance at $760 \mathrm{~nm}$ in quartz cuvettes of $1 \mathrm{~cm}$ optical path with ultrapure water as white. The calibration curve was prepared with gallic acid (25-1000 $\mu \mathrm{g} \cdot \mathrm{mL}^{-1} ; \mathrm{Y}=0.12951 \mathrm{X}+0.12497 ; \mathrm{R}=0.999$ ). Total phenolic content was calculated and expressed as milligrams of gallic acid equivalents per $100 \mathrm{mg}$ of extract (mg $\mathrm{E}_{\mathrm{AG}} 100$ $\mathrm{mg}^{-1}$ ).

\subsection{Determination of total flavonoid} content
Total flavonoid content was determined using by adapting a methodology using aluminum chloride as reagent. ${ }^{25,26}$ This method is specific for flavones and flavonols. Spectroscopic methanol (Sigma Aldrich) was used to prepare solutions of $5 \mathrm{mg} \mathrm{mL}^{-1}$ of rhizome extracts. The calibration curve was prepared with quercetin $\left(1-50 \mu \mathrm{g} \cdot \mathrm{mL}^{-1}, \mathrm{Y}=\right.$ $0.06553+0.04078 X, R=0.999)$. The results were expressed as $\mathrm{mg}$ of quercetin equivalents per 100 mg extract (mg EQ 100 $\left.\mathrm{mg}^{-1}\right)$.

\subsection{Free-radical scavenging assay (DPPH)}

Seventy-one microliters of rhizome extract solution $\left(25-150 \mu \mathrm{g} \cdot \mathrm{mL}^{-1}\right)$ were mixed with 29 $\mu \mathrm{L}$ of $0.3 \mathrm{mmol} . \mathrm{L}^{-1} \mathrm{DPPH}$ methanol solution. The absorbance was measured after $30 \mathrm{~min}$ at $517 \mathrm{~nm}$ using an ELISA 680 microplate reader (Bio-Rad, Brazil). The results were expressed as $E_{50} \mu \mathrm{g} \cdot \mathrm{mL}^{-1}$, that is, the amount of antioxidant needed to decrease the initial DPPH concentration by $50 \%$.

2.7. Evaluation of antioxidant activity by ferric-reducing antioxidant power assay (FRAP)

A $0.5-\mathrm{mL}$ aliquot of rhizome extracts $(1.00$ $\mathrm{mg} \cdot \mathrm{mL}^{-1}$ ) was mixed with $4.5 \mathrm{~mL}$ of FRAP reagent. The absorbance was read after 10 min of incubation at $37{ }^{\circ} \mathrm{C}$ at $593 \mathrm{~nm}$ using ultrapure water as white. The calibration curve was prepared with $\mathrm{FeSO}_{4} .7 \mathrm{H}_{2} \mathrm{O}$ (100$1000 \mu \mathrm{M}, \mathrm{Y}=0.0018 \mathrm{X}+0.00107, \mathrm{R}=0.99961$ ) and the results expressed as mmol Fe(II) 100 $\mathrm{mg}^{-1}$.

2.8. Determination of antioxidant activity by radical-cation scavenging (ABTS ${ }^{+}$)

A $50 \mu \mathrm{L}$ aliquot of rhizome extracts $(1.00$ $\mathrm{mg} \cdot \mathrm{mL}^{-1}$ ) was mixed with $5.0 \mathrm{~mL}$ of ABTS reagent. The absorbance was read after $6 \mathrm{~min}$ 
at $734 \mathrm{~nm}$ using ethyl alcohol as white. The calibration curve was prepared with Trolox (0.00-2.40 mmol..-1; $Y=-26.37778 \mathrm{X}+$ $0.65164 ; R=-0.9997)$. The results were expressed in mmol TE $100 \mathrm{mg}$.

\subsection{Statistical analyzes}

The analyses were performed with three replicates and results were presented as mean \pm standard deviation (SD). Pearson correlation, which indicates the positive or negative existence between two variables, was adopted in order to investigate correlation between total phenolic content and the extracts antioxidant activity. The statistical analyzes were performed using the $\mathrm{R}$ program.

\section{Results and Discussion}

\subsection{Secondary metabolites in rhizomes}

In cross section, $R$. breviscapa and $R$. nicolaioides showed an uniseriate epidermis, and $R$. chrysotricha presented a stratified suber. The phenolic compounds were concentrated at the subepidermal layer in $R$. breviscapa and $R$. nicolaioides (Figure $1 \mathrm{~A}$ ) and in the stratified suber of $R$. chrysotricha (Figure 1B), but were also scattered randomly throughout the cortex (Figure 1A-B and 1F) and the vascular cylinder (Figures $1 C-D$ ), as well as near the vascular bundle (Figures 1E).

We identified phenolic compounds in the rhizomes of three studied species. According to Tomlinson (1956), a pioneer in studies on morphology of Zingiberaceae, tannin was characteristic in all species of this family, and these compounds were very frequent associated with vascular bundles. Further anatomical and histochemical studies showed phenolic idioblasts in other species of Zingiberaceae. ${ }^{10,27-30}$ Polyphenolic secondary metabolites were found in the underground organs and probably related to plant defense against microbial pathogens..$^{31}$

\subsection{Total phenolic and flavonoid content}

Values of total phenolic (TP) and total flavonoid (TF) content of the samples are presented in Table 1. The values of TP varied between 32.56 and $33.66 \mathrm{mg} \mathrm{E}_{\mathrm{GA}} 100 \mathrm{mg}^{-1}$ in R. nicolaioides; 1.49 and $15.09 \mathrm{mg} \mathrm{E}_{\mathrm{GA}} 100 \mathrm{mg}$ ${ }^{1}$ in R. chrysotricha; 3.20 and $5.53 \mathrm{mg} \mathrm{E}_{\mathrm{GA}} 100$ $\mathrm{mg}^{-1}$ in $R$. breviscapa (Table 1 ).

The TF results ranged between 2.3 to 5.12 $\mathrm{mg}$ EQ $100 \mathrm{mg}^{-1}$ in $R$. nicolaioides, 0.07 to 0.74 $\mathrm{mg} \mathrm{E}_{\mathrm{Q}} 100 \mathrm{mg}^{-1}$ in $R$. chrysotricha, and 0.10 to $0.46 \mathrm{mg} \mathrm{E}_{\mathrm{Q}} 100 \mathrm{mg}^{-1}$ in $R$. breviscapa (Table 1).

Following the histochemical tests, the phenolic compounds identified in the rhizomes of three studied species were quantified. The extracts from $R$. nicolaioides showed the highest total phenolic and flavonoid contents. Diarylheptanoids, 1,7bis(4-hydroxyphenyl)-(1E)-1-hepten-3-one, 5R-1,7-bis(4-hydroxyphenyl)-1E-hepten-5-ol and $\quad(1 R, 2 S, 5 S)$-2-hydroxy-1,7(phydroxyphenyl)-centrolobine, as well as one flavonoid, 3-metoxi-quercetin, have been recently isolated from $R$. nicolaioides rhizome extracts. $^{32}$

The flavonoid (flavones and flavonols) content was low in the three extracts and corresponded to $3.12-15.63 \%$ of the TP. These results may be related to the diversity of flavonoid types (chalcones, flavanones, flavones, flavones, catechins) found in Renealmia species, as well as the tendency for rhizomes to accumulate diarylheptanoids, another class of phenolic compounds. ${ }^{32-37}$

\subsection{Antioxidant capacity}

Table 2 shows the results of the antioxidant activity of rhizome extracts from Renealmia species tested by three different methods, DPPH, FRAP and ABTS. 

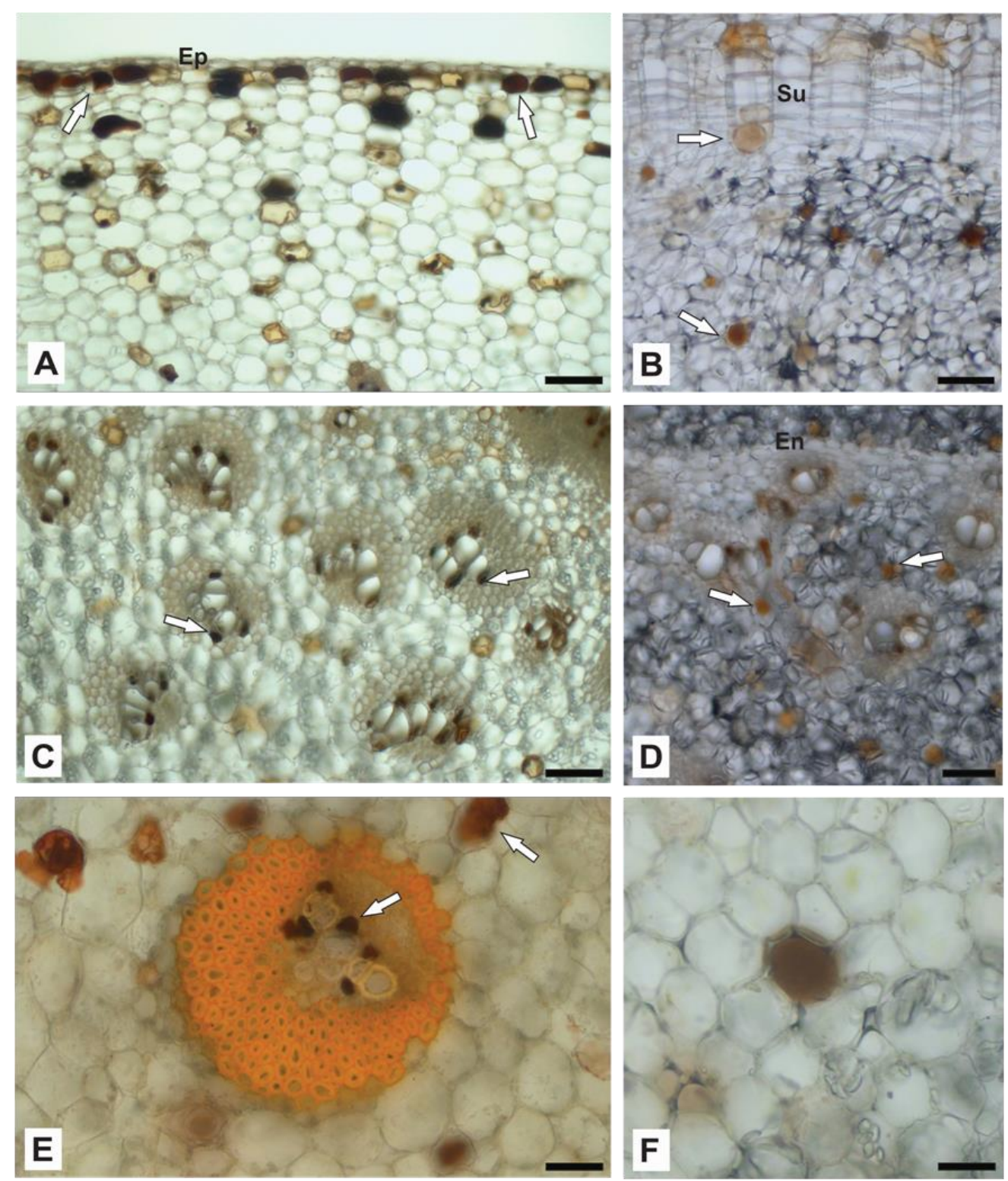

Figure 1. Phenolic compounds of Renealmia rhizome (TS). (A, $C$ and $E$ ) $R$. nicolaioides. (B, D and F) R. chrysotricha. (A-D and F) Phenolic compounds stained by $10 \%$ potassium dichromate. (A, B) Cortical region. (C, D) Central cylinder. (E) Phenolic compounds evidenced by HoephnerVorsatz test. $\mathrm{Ep}=$ epidermis, $\mathrm{Su}=$ stratified suber, $\mathrm{En}=$ endodermis. Bars $=100 \mu \mathrm{m}(\mathrm{A}-\mathrm{D})$; $50 \mu \mathrm{m}(\mathrm{E}, \mathrm{F})$ 
Table 1. Total Phenolic (TP) and Total Flavonoid (TF) content for eight extracts of the studied rhizomes

\begin{tabular}{|c|c|c|}
\hline Samples & $\begin{array}{l}\text { Total Phenolic Content (mg } \mathrm{E}_{\mathrm{AG}} 100 \mathrm{mg}- \\
\left.1^{-}\right)^{\mathrm{a}}\end{array}$ & $\begin{array}{l}\text { Flavonoid Content (mg EQ } \\
\left.\qquad 100 \mathrm{mg}^{-1}\right)^{\mathrm{b}}\end{array}$ \\
\hline RNM-D & $33.66 \pm 0.072$ & $2.30 \pm 0.001$ \\
\hline RNM-Aq & $32.77 \pm 0.024$ & $5.12 \pm 0.001$ \\
\hline RNM & $32.56 \pm 0.026$ & $2.85 \pm 0.000$ \\
\hline RCM-Ac & $15.09 \pm 0.012$ & $0.74 \pm 0.001$ \\
\hline RBM & $5.53 \pm 0.005$ & $0.46 \pm 0.001$ \\
\hline RBM-Aq & $3.20 \pm 0.007$ & $0.10 \pm 0.000$ \\
\hline RCM & $2.10 \pm 0.031$ & $0.07 \pm 0.001$ \\
\hline RCM-Aq & $1.49 \pm 0.004$ & $0.14 \pm 0.001$ \\
\hline
\end{tabular}

a- $\mathrm{mg}$ of gallic acid equivalents per $100 \mathrm{mg}$ of extract; $\mathrm{b}$ - $\mathrm{mg}$ of quercetin equivalents per 100 $\mathrm{mg}$ of extract; RNM-D - dichloromethane fraction of $R$. nicolaioides; RNM-Aq - aqueous fraction of $R$. nicolaioides; RNM - methanolic extract of $R$. nicolaioides; RCM-Ac - ethyl acetate fraction of $R$. chrysotrycha; RBM - methanolic extract of $R$. breviscapa; RBM-Aq - aqueous fraction of $R$. breviscapa; RCM - methanolic extract of $R$. chrysotrycha; RCM-Aq - aqueous fraction of $R$. chrysotrycha

Table 2. Antioxidant activity of rhizome extracts

\begin{tabular}{cccc}
\hline Samples & $\begin{array}{c}\text { DPPH }\left(\mathrm{CE}_{50}\right) \\
\left(\mathbf{m g ~ m L} \mathbf{~ m L}^{-1}\right)\end{array}$ & $\begin{array}{c}\text { FRAP } \\
\left(\mu \mathrm{mol} \mathrm{Fe}(\mathrm{II}) \mathbf{1 0 0} \mathbf{m g}^{-1}\right)\end{array}$ & $\begin{array}{c}\text { ABTS } \\
\left(\mu \mathrm{mol} \mathrm{TE} \mathbf{1 0 0} \mathbf{~ m g}^{-1}\right)\end{array}$ \\
\hline RNM & $13.80 \pm 0.26$ & $614.59 \pm 0.06$ & $182.76 \pm 0.00$ \\
RNM-Aq & $13.95 \pm 0.16$ & $478.66 \pm 0.12$ & $223.73 \pm 0.00$ \\
RNM-D & $30.40 \pm 1.07$ & $586.44 \pm 0.08$ & $199.22 \pm 0.01$ \\
RBM & $50.12 \pm 2.99$ & $125.55 \pm 0.08$ & $44.98 \pm 0.00$ \\
RCM-Ac & $61.36 \pm 1.36$ & $346.44 \pm 0.04$ & $109.75 \pm 0.01$ \\
RCM-Aq & $97.35 \pm 0.96$ & $28.51 \pm 0.01$ & $17.41 \pm 0.01$ \\
RBM-Aq & $122.25 \pm 4.07$ & $39.55 \pm 0.03$ & $35.58 \pm 0.00$ \\
RCM & $155.85 \pm 8.28$ & $21.33 \pm 0.00$ & $23.30 \pm 0.00$ \\
\hline
\end{tabular}

RNM - methanolic extract of $R$. nicolaioides; RNM-Aq - aqueous fraction of $R$. nicolaioides; RNM-D - dichloromethane fraction of $R$. nicolaioides; RBM - methanolic extract of $R$. breviscapa; RCM-Ac - ethyl acetate fraction of $R$. chrysotrycha; RCM-Aq - aqueous fraction of $R$. chrysotrycha; RBM-Aq - aqueous fraction of $R$. breviscapa; RCM - methanolic extract of $R$. chrysotrycha 
We found a significant correlation between total phenolic content and the antioxidant activity in relation to FRAP and ABTS assays of the extracts (Table 3 ).

Table 3. Correlations between total phenolic content, total flavonoid content and antioxidant activity (DPPH, FRAP and ABTS) of rhizome extracts, by the Pearson method

\begin{tabular}{cccccc}
\hline & TP & TF & DPPH & FRAP & ABTS \\
\hline TP & ----- & 0.88 & -0.84 & 0.98 & 0.99 \\
TF & 0.88 & ----- & -0.78 & 0.79 & 0.92 \\
DPPH & -0.84 & -0.78 & ---- & -0.86 & -0.85 \\
FRAP & 0.98 & 0.79 & -0.86 & ----- & 0.96 \\
ABTS & 0.99 & 0.92 & -0.85 & 0.96 & ----- \\
\hline
\end{tabular}

The methods used to test the antioxidant capacity are widely used due to their simplicity, fast acquisition data, sensitivity and reproducibility. ${ }^{38}$ Despite all the extracts exhibited antioxidant capacity, the best results were obtained by $R$. nicolaioides extracts. The values of the DPPH assays, expressed in $\mathrm{EC}_{50}$, were higher and less effective than those obtained from other Zingiberaceae species, such as Amomum muricarpum Elmer, Etlingera philippinensis (Ridl.) R. M. Sm. and Hornstedtia conoidea Ridl. ${ }^{19}$

We found significant correlation between total phenolic content and the antioxidant activity in relation to FRAP and ABTS assays of the extracts, as observed for extracts from other Zingiberaceae species. ${ }^{12,15-18,20}$

This study suggests Renealmia species are sources of phenolic compounds that may contribute to the treatment of diseases and degenerative processes associated with the overproduction of reactive oxygen species, an under exploited issue up to date.

\section{Acknowledgments}

This study was financed in part by the Coordenação de Aperfeiçoamento de Pessoal de Nível Superior - Brasil (CAPES) - Finance Code 001; Conselho Nacional de Desenvolvimento Científico e Tecnológico (CNPq); the Fundação de Amparo à Pesquisa do Rio de Janeiro (FAPERJ). This study was part of the thesis of the first author at Programa de Pós-Graduação em Biociências e Biotecnologia/UENF.

\section{References}

${ }^{1}$ Dai, J.; Mumper, R. J. Plant Phenolics: Extraction, Analysis and Their Antioxidant and Anticancer Properties. Molecules 2010, 15, 7313. [CrossRef]

2 Rice-Evans, C. A.; Nicholas J.; Millerl, N. J.; George Paganga, G. Structure-antioxidant activity relationships of flavonoids and phenolic acids. Free Radical Biology and Medicine 1996, 20, 933. [CrossRef]

${ }^{3}$ Bravo, L. Polyphenols: Chemistry, Dietary Sources, Metabolism, and Nutritional Significance. Nutrition Reviews 1998, 56, 317. [CrossRef]

${ }^{4}$ Csepregi, K.; Neugart, S.; Schreiner, M.; Hideg, E. Comparative evaluation of total antioxidant capacities of plant polyphenols. Molecules 2016, 21, 208. [CrossRef] 
${ }^{5}$ Yashin, A.; Yashin, Y.; Xia, X.; Nemzer, B. Antioxidant of spices and their impact on human health: A review. Antioxidants 2017, 6. [CrossRef]

${ }^{6}$ Maas, P. J. M.; Renealmia (ZingiberaceaeZingiberoideae), Costoideae (Zingiberaceae). Flora Neotropica, The New York Botanical Garden: New York, 1977.

${ }^{7}$ Kress, W. J.; Prince, L. M.; Williams, K. J. The phylogeny and a new classification of the gingers (Zingiberaceae): Evidence from molecular data. American Journal of Botany, 2002, 89, 1682. [CrossRef]

${ }^{8}$ Maas, P. J. M.; Maas, H.; Zingiberaceae in Lista de Espécies da Flora do Brasil, Jardim Botânico do Rio de Janeiro: Rio de Janeiro, 2015.

${ }^{9}$ Negrelle, R. R. B. Renealmia L.f.: aspectos botânicos, ecológicos, farmacológicos e agronômicos. Revista Brasileira de Plantas Medicinais 2015, 17, 274.[CrossRef]

${ }^{10}$ Gevú, K. V.; Da Cunha, M.; Barros, C. F.; Pereira, S. M.; Lima, H. R. P. Structural analysis of subterranean organs in Zingiberaceae. Plant Systematics and Evolution 2014, 300, 1089. [CrossRef]

${ }^{11}$ Habsah, M.; Amran, M.; Mackeen, M. M.; Lajis, N. H.; Kikuzaki, H.; Nakatanib, N.; Rahman, A. A.; Ghafar; Ali, A. M. Screening of Zingiberaceae extracts for antimicrobial and antioxidant activities. Journal of Ethnopharmacology 2000, 72, 403. [PubMed]

${ }^{12}$ Chan, E. W. C.; Lim, Y. Y.; Omar, M. Antioxidant and antibacterial activity of leaves of Etlingera species (Zingiberaceae) in Peninsular Malaysia. Food Chemistry 2007, 104, 1586. [CrossRef]

${ }^{13}$ Chen, I.; Chang, C.; Ng, C.; Wang, C.; Shyu, Y.; Chang, T. Antioxidant and antimicrobial activity of Zingiberaceae plants in Taiwan. Plant Foods for Human Nutrition 2008, 63, 15. [CrossRef] [PubMed]

${ }^{14}$ Rawat, S.; Bhatt, I. D.; Rawal, R. S. Total phenolic compounds and antioxidant potential of Hedychium spicatum Buch. Ham. ex D. Don in west Himalaya, India. Journal of Food Composition Analysis 2011, 24, 574.

\section{[CrossRef]}

${ }^{15}$ Chan, E. W. C.; Lim, Y. Y.; Wong, S. K. Antioxidant properties of ginger leaves: An overview. Free Radicals and Antioxidants 2011, 1, 6. [CrossRef]

${ }^{16}$ Chan, E. W. C.; Ng, V. P.; Tan, V. V.; Low, Y. Y. 2011. Antioxidant and antibacterial properties of Alpinia galanga, Curcuma longa, and Etlingera elatior (Zingiberaceae). Pharmacognosy Journal 2011, 3, 54. [CrossRef]

${ }^{17}$ Akinola, A. A.; Syahida, A.; Maziah, M. Total antioxidant capacity, flavonoid, phenolic acid and polyphenol content in tem selected species of Zingiberaceae rhizomes. African Journal of Traditional, Complementary and Alternative Medicines 2014, 11, 7. [CrossRef] [PubMed]

${ }^{18}$ Adekoya, A. A.; Ahmad, S.; Maziah, M. Assessment of total phenolic compounds and in vitro free radical scavenging potentials of water extracts of ten selected species of Zingiberaceae rhizomes use in folkloric medicine. Pakistan Journal of Pharmaceutical Science 2016, 29, 979. [PubMed]

${ }^{19}$ Barbosa, G. B.; Peteros, N. B.; Inutan, E. D. Antioxidant activities and phytochemical screening of Amomum muricarpum, Hornstedtia conoidea and Etlingera philippinensis. Bulletin of Environment, Pharmacology and Life Sciences 2016, 5, 22. [Link]

${ }^{20}$ Soumya, T.; Theyyankandi, L.; Rajamma, J. P.; Ramakrishnan, M. K. P. Evaluation of total phenolics, antioxidant and antiproliferative activities of rhizome extracts from select Zingiberaceae species in South India. International Journal of Phytomedicine 2016, 8, 337. [CrossRef]

${ }^{21}$ Gabe M.; Techniques histologiques. Masson \& Cie: Paris, 1968.

${ }^{22}$ Reeve, R. M. Histochemical test for polyphenols in plant tissues. Stain Technology 1951, 26, 91. [CrossRef]

${ }^{23}$ Folin, O.; Denis, W. On phosphotungsticphosphomolybdic compounds as color reagents. Journal of Biological. Chemistry 1912, 12, 239. [Link] 
${ }^{24}$ Sant'ana, L. D 'O.; Sousa, J. P. L. M.; Salgueiro, F. B.; Lorenzon, M. C. A.; Castro, R. $N$. Characterization of Monofloral Honeys with Multivariate Analysis of Their Chemical Profile and Antioxidant Activity. Journal of Food Science 2012, 77, 135. [CrossRef] [PubMed]

${ }^{25}$ Meda, A.; Lamien, C. E.; Romito, M.; Millogo, J.; Nacoulma, O. G. Determination of the total phenolic, flavonoid and proline contents in Burkina Fasan honey, as well as their radical scavenging activity. Food Chemistry 2005, 91, 571. [CrossRef]

${ }^{26}$ Pérez, R. A.; Iglesias, M. T.; Puyeo, E.; González, M.; De Lorenzo, C. Amino Acid Composition and Antioxidant Capacity of Spanish Honeys. Journal of. Agricultural and Food Chemistry 2007, 55, 360. [CrossRef] [PubMed]

${ }^{27}$ Sherlija, K. K.; Remashree, A. B.; Unnikrishnaw, K.; Ravindran, P. N. Comparative rhizome anatomy of four species of Curcuma. Journal of Spices and Aromatic Crops 1998, 7, 103.

${ }^{28}$ Albuquerque, E. S. B.; Neves, L. J. Anatomia foliar de Alpinia zerumbet (Pers.) Burtt \& Smith (Zingiberaceae). Acta Botanica Brasílica 2004, 18, 109. [CrossRef]

${ }^{29}$ Tang, Y.; Liao, J.; Wu, Q. Comparative anatomy of the leaves of Amomum (Zingiberaceae). Subtropical Plant Science 2010, 03.

${ }^{30}$ Uma, E.; Muthukumar, T. Comparative root morphological anatomy of Zingiberaceae. Systematics and Biodiversity 2014, 12, 195. [CrossRef]

${ }^{31}$ Dixon, R. A.; Xie, D.; Sharma, S. B. Proanthocyanidins - a final frontier in flavonoid research? New Phytologist 2005, 165, 9. [CrossRef] [PubMed]

${ }^{32}$ Gevú, K. V.; Carvalho, M. G.; Silva, I. G.; Lima, H. R. P.; Castro, R. N.; Da Cunha, M. Phenolic compounds from rhizome of
Renealmia nicolaioides Loes.: a new diarylheptanoid. Anais da Academia Brasileira de Ciências, 2019, 91, 1. [CrossRef]

${ }^{33} \mathrm{Gu}$, J.; Vigo, J. S.; Graham, J. G.; Fong, H. H. S.; Pezzuto, J. M.; Kinghorn, A. D. ActivityGuided Isolation of Constituents of Renealmia nicolaioides with the Potential to Induce the Phase II Enzyme Quinone Reductase. Journal of Natural Products 2002, 65, 1616. [CrossRef] [PubMed]

${ }^{34}$ Cabanillas, B. J.; Lamer, A. L.; Olagnier, D.; Castillo, D.; Arevalo, J.; Valadeau, C.; Coste, A.; Pipy, B.; Bourdy, G.; Sauvain, M.; Fabre, N. Leishmanicidal compounds and potent PPARyactivators from Renealmia thyrsoidea (Ruiz \& Pav.) Poepp. \& Endl. Journal of Ethnopharmacoly 2014, 157, 149. [CrossRef]

${ }^{35}$ Gilli, C.; Orlowska, E.; Kaiser, D.; Steyrer, J.; Rathgeb, A.; Lorbeer, E.; Brecker, L.; Schinner, J. Diarylheptanoids, flavonoids and other constituents from two neotropical Renealmia species (Zingiberaceae). Biochemical Systematics and Ecology 2014, 56, 178. [CrossRef]

${ }^{36}$ Gómez-Betancur, I.; Benjumea, D.; Patiño, A.; Jiménez, N.; Osório, E. Inhibition of the toxic effects of Bothrops asper venom by pinostrobin, a flavanone isolated from Renealmia alpinia (Rottb.) MAAS. Journal of Ethnopharmacoly 2014, 155, 1609. [CrossRef] [PubMed]

${ }^{37}$ Gómez-Betancur, I.; Cortés, N.; Benjumea, D.; Osório, E.; León, F.; Cutler, S. J. Antinociceptive activity of extracts and secondary metabolites from wild growing and micropropagated plants of Renealmia alpinia. Journal of Ethnopharmacoly 2015, 165, 191.[CrossRef] [PubMed]

${ }^{38}$ Salgueiro, F. B.; Castro, R. N. Comparação entre a composição química e a capacidade antioxidante de diferentes extratos de própolis verde. Química Nova 2016, 39, 1192. [CrossRef] 